\title{
STORY COUNTY'S CIVIL WAR RESOLUTION
}

\author{
Edited by David M. Wilcox
}

Mr. Wilcox is a graduate student and teaching assistant in American History at Iowa State University, Ames, Iowa. In these capacities and as the assistant to the director of the Department of Special Collections at the Iowa State Library, he has developed an interest in relating local Iowa history to the history of the United States. As a result, he has edited the document below to give relevance to what might otherwise have remained a forgotten example of Iowa's Civil War past.

\section{INTRODUCTION}

The territorial government of Iowa first established county boards of supervisors in 1838. Compared to today, the county boards assumed much more jurisdictional power but in fewer areas of government. They literally governed the counties, levying taxes and conducting all county business, but primarily, focusing on matters concerning their local communities. ${ }^{1}$

One reason why Story County's Civil War resolution generates interest is because it deals with none of the responsibilities just mentioned. Surrounded by figures concerning property values and salary allocations, this "Resolution" focuses on the problems of the Civil War and the Nation. Found in the Auditor's Office ${ }^{2}$ of the Story County Courthouse, this document exemplifies the patriotism that Iowans felt during one of the most exciting periods in American history. In this, the first of thirteen volumes of the Supervisor's Minute Book, dated from January 7, 1861 to June 8, 1868, are the lines directed to the people of Story County.

${ }^{1}$ All the information in this first paragraph was obtained in an interview with the Story County Auditor, Mrs. Dorothy J. Elliot on February 2, 1971 .

${ }^{2}$ Records of the Board are kept in the Auditor's Office because the County Auditor is also the Clerk of the Board of Supervisors. 


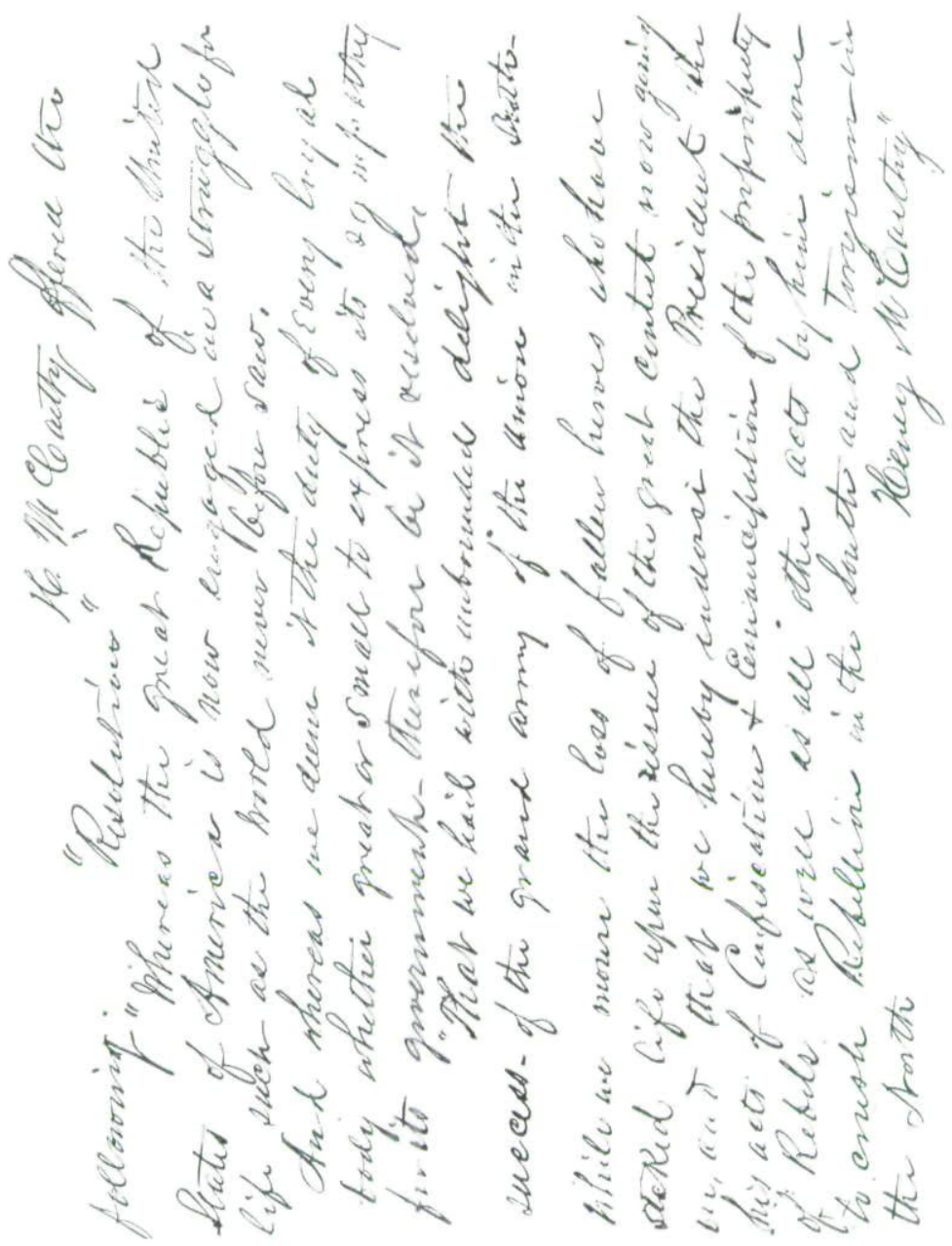


January 10,1863

the following

H. McCarthy ${ }^{3}$ offered

\section{"Resolution"}

"Whereas the great Republic of the United States of America is now engaged in a struggle for life such as the world never before saw, And whereas we deem it the duty of every loyal body whether great or small ${ }^{4}$ to express its sympathy for its government-therefore be it resolved,

"That we hail with unbounded delight the success of the grand army of the Union in the South ${ }^{5}$ While we mourn the loss of fallen heroes who have staked life upon the issue of the great contest now going on, and that we hereby endourse the President for his acts of Confiscation ${ }^{6}$ \& Emancipation ${ }^{7}$ of the

${ }^{3}$ Henry McCarthy is identified on page 152 of the Minute Book as the Chairman of the Board's Finance Committee. Sworn into office only five days prior to the presentation of this resolution, McCarthy represented Washington township-a township which presently lies southeast of the Iowa University campus.

With respect to Iowa history, not much has been written about Henry McCarthy. His life and noteworthy contributions to Story County have generally been overshadowed by his younger brother, Daniel McCarthy. Nevertheless, in an article written by Earle D. Ross in the Centennial Addition of the Ames Daily Tribune (September 5, 1964), McCarthy was said to have been an avid promoter of the small agricultural college located in Ames. In fact, he sold much of his own land at a reduced price as his contribution to the college that would become Iowa State University.

${ }^{4}$ Perhaps this phrase, "the duty of every loyal body whether great or small," provides the supervisor's justification for side-stepping their regular duties and endorsing the policies of the Union.

${ }^{5}$ During the seven months preceding this resolution, the Union armies defeated the Southern forces at Shiloh (April 6-7, 1862), at Perryville, Kentucky (October 8, 1862), and in the battle of Murfreesboro on Stone River (December 31, 1862 through January 3, 1863).

${ }^{6} \mathrm{McCarthy}$ is probably referring to the two acts of confiscation passed in August of 1861 and July of 1862. The first federal confiscation acts authorized seizure of all property, including slaves, being used in the rebellion. The second act, in addition to providing special punishment for persons convicted of treason in the rebellion and providing for confiscation of property, other than slaves, gave freedom to all whose masters were aiding the Confederacy.

${ }^{7}$ The Emancipation Proclamation, issued by President Lincoln in 


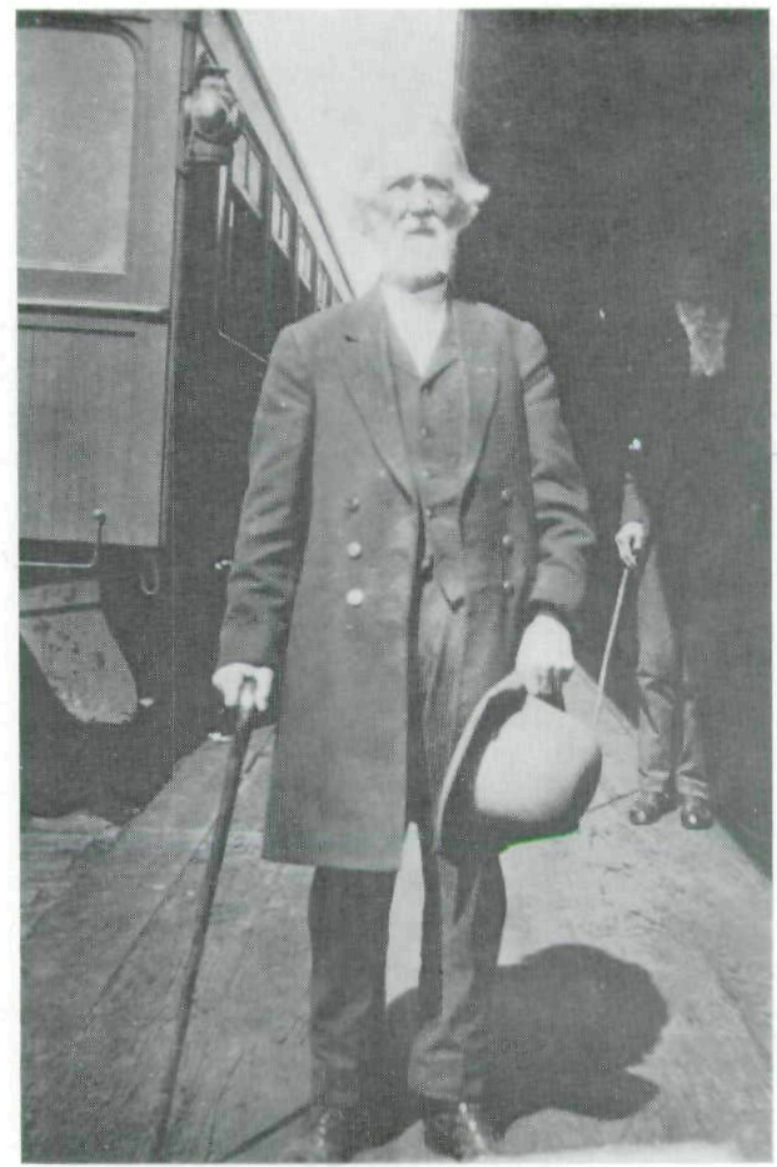

Dept. of Special Collections, I.S.U. Library

Henry McCarthy

Story County Pioneer 
property $^{8}$ of Rebels as well as all other acts by him done to crush Rebellion in the South and toryism ${ }^{9}$ in the North

Henry McCarthy"

September of 1862, gave Southerners the alternative of ceasing their rebellion by January 1,1863 or to suffer economic loss through the freeing of their slaves.

${ }^{8}$ Slaves, at this time, were regarded as property. The Dred Scott decision, issued March 7, 1857, legally supported this idea by stating that a slave, whether living in a slave state or a free state, was the property of his owner.

${ }^{9}$ According to Mitford Mathews' A Dictionary of Americanisms on Historical Principles, a tory is "a person regarded as disloyal; a traitor." Therefore, "toryism in the North" refers to the Northerners disloyal to the Union. This term is somewhat confusing in that there were more popular words used during the Civil War to identify Southern sympathizing Northerners, such as "Copperheads" and "Doughfaces".

Reprint from: Dubuque Times-Journal, October 29, 1922

\section{IOWA IS HOME OF LONE SURVIVOR OF "THE GALLANT SIX HUNDRED"}

Cedar Rapids, Ia., Oct. 28,-Ellis Cutting, sole survivor of the famous "Charge of the Light Brigade," rode unscathed through that gallant but futile action- to be hurt by a snow plow near here.

Today, 68 years after the immortal execution of blundered orders, Cutting, 85, is alive and alert. He recalls as though it were yesterday the charge at Balaklava, in which he participated as a youth of 17 , the charge of Tennyson's poem immortalized.

With the Crimean war in progress-Britain and France allied with Turkey against Russia-the Russians attacked the allies at Balaklava Oct. 25, 1854, hoping to cut allied communications.

The "Heavy Brigade" of British cavalry made a furious charge, swept back the attackers and drove them back behind their own artillery. 
Copyright of Annals of Iowa is the property of State of Iowa, by \& through the State Historical Society of Iowa and its content may not be copied or emailed to multiple sites or posted to a listserv without the copyright holder's express written permission. However, users may print, download, or email articles for individual use. 